\title{
Extracellular Matrix: A Treasure Trove in Ovarian Cancer Dissemination and Chemotherapeutic Resistance
}

Surbhi Valmiki ${ }^{1}$, Mohamed A. Aid ${ }^{2,3}{ }^{3}$, Ali R. Chaitou ${ }^{4,5}$, Maria Zahid ${ }^{4}$, Mrinaal Valmiki ${ }^{6}$, Peter Fawzy ${ }^{7}$, Safeera Khan ${ }^{4}$

1. Obstetrics and Gynecology, California Institute of Behavioral Neurosciences \& Psychology, Fairfield, USA 2. Intensive Care Unit, California Institute of Behavioral Neurosciences \& Psychology, Fairfield, USA 3. Intensive Care Unit, King Fahad Military Medical Complex, Jeddah, SAU 4. Internal Medicine, California Institute of Behavioral Neurosciences \& Psychology, Fairfield, USA 5. Internal Medicine, Faculty of Medical Sciences, Lebanese University, Beirut, LBN 6. Psychiatry, California Institute of Behavioral Neurosciences \& Psychology, Fairfield, USA 7. Neurological Surgery, California Institute of Behavioral Neurosciences \& Psychology, Fairfield, USA

Corresponding author: Surbhi Valmiki, surbhivalmiki12@gmail.com

\begin{abstract}
Late presentation and resistance to chemotherapeutic agents make a deadly combination for ovarian cancer patients. The treatment of these patients is thus challenging. This study explores the possible molecular mechanisms by which tumor cells interact with the extracellular matrix (ECM) constituents, forming metastatic implants and enhancing patients' sensitivity to drugs. For the literature review, PubMed was used as a database. The standard search was done using keywords "collagen, ovarian cancer, extracellular matrix, drug resistance" in different combinations, which finally yielded 32 studies meeting the inclusion/exclusion criteria. The studies included were published in the English language in the past seven years.
\end{abstract}

After analyzing, we found all of them to be histopathological studies. Nine studies also used murine cell lines besides human cell lines and tissue samples from ovarian cancer patients. One study has a retrospective analysis done. Eight studies demonstrate the role of hypoxia and matrix remodeling enzymes in ovarian cancer dissemination. Genetics playing a crucial role in cancer metastasis is demonstrated in eight studies. Ten studies included shows receptors, enzymes, and spheroid organization in disease progression. Six studies address chemotherapeutic resistance. Intraperitoneal dissemination of ovarian cancer and the development of chemotherapeutic resistance depends on certain molecular interactions, and they can be targeted to improve patients' overall survival.

Categories: Obstetrics/Gynecology

Keywords: collagen, ovarian cancer, extracellular matrix, drug resistance

Received 01/28/2021 Review began 02/15/2021 Review ended 03/07/2021 Published 03/13/2021

(c) Copyright 2021 Valmiki et al. This is an open access article distributed under the terms of the Creative Commons Attribution License CC-BY 4.0, which permits unrestricted use, distribution, and reproduction in any medium, provided the original author and source are credited.

\section{Introduction And Background}

Ovarian cancer remains the most lethal of all gynecological cancers, with approximately 14,000 deaths each year in the United States [1]. The Annual Incidence reported in the year 2018 was 22,240 [1]. Ovarian cancer patients are often asymptomatic and are not recognized until late in the disease course. The patients usually present with distant metastasis and malignant ascites hurting the overall survival. The patients initially respond to debulking surgery and chemotherapeutic regimen usually consisting of a platinum complex (cisplatin or carboplatin) and a taxane (paclitaxel or docetaxel), nearly $80 \%$ eventually relapse into chemoresistant cases resulting in a five-year survival rate of $30 \%$ [2].

Unlike most solid tumors, which spread via lymphatic or hematogenous routes, ovarian cancer cells disseminate through direct extension into the peritoneum by shedding either as a single cell or multicellular aggregates (MCA), which interact with mesothelial cells lining the peritoneum, later invading the underlying basement membrane and spreading across the extracellular matrix (ECM) forming metastatic implants [3]. The extracellular matrix is mainly composed of collagen, laminin, fibronectin, vitronectin, proteoglycans, and gelatin, which also play a vital role in tumor invasion.

Cancer metastasis is a key component driving disease progression and patient survival, but the molecular mechanisms underlying it remains understudied. Previous studies described the role of hypoxia and hypoxia-inducible factor- $\alpha$ (HIF- $\alpha$ ) in ovarian cancer proliferation and invasion $[4,5]$. Zhao et al. uncovered the role of an angiotensin receptor blocker (AT-1 receptor blocker) Losartan in decreasing the proliferation of ECM protein collagen, thereby leading to lesser drug resistance and decreased ascites in patients [6]. Several pathways (Janus kinase and signal transducer and activator of transcription proteins JAK/STAT3, mitogen-activated protein kinase-7 MAPK-7) [7,8], cell surface receptors like integrins [9], proteins such as microfibril-associated protein-5 (MFAP-5) [10], Tau protein [11], collagen triple helix repeat containing-1 (CTHRC-1) [12], receptors such as discoidin domain receptor-2 (DDR-2) [13], formyl peptide receptor type 1 (FPR1) [14], cytokines like transforming growth factor- $\beta$ (TGF- $\beta$ ) [15], enzymes such as lysyl oxidase (LOX) 
[4], integrin-linked kinase (ILK) [16], and histone deacetylase-4 (HDAC-4) have been well characterized in the literature [17]. Glucocorticoids have also been shown to be associated with tumor cell adhesion and resistance to chemotherapeutic agents [18]. Further knowledge regarding the tumor-stromal interactions in the tumor microenvironment could help physicians sort preventive measures to decrease the morbidity and mortality associated with the disease.

Despite all the studies, little is known regarding the molecular mechanisms of tumor cell-mesenchymal cell interactions underlying metastasis. The studies described in this review mainly address the studies that have been done on tissue samples obtained from post-operative patients with ovarian cancer or the cell lines purchased from repositories. Nevertheless, the phenomenon of tumor seeding onto the peritoneum and peritoneal organs causing bowel obstruction, ascites leading to impaired circulation, and impaired drug delivery need further exploration in in-vivo experiments on human subjects.

The following research paper aims to review all the possible mechanisms of tumor proliferation, invasion, and metastasis, the role of ECM in intraperitoneal dissemination of tumor cells, and enhancing the sensitivity to chemotherapeutic agents discovered in the year 2013-2020. Our study reviews the role of the tumor microenvironment, receptors, pathways/regulators that may serve as therapeutic targets in the disease progression of ovarian cancer patients.

\section{Review}

\section{Methods}

This traditional review was done without following PRISMA guidelines. The PRISMA flow diagram was however, included to explain the search strategy.

\section{Search Strategy}

A detailed literature review was done using the PubMed database for studies published from January 2013 to November 2020. The search for the studies was done manually using the regular keywords "collagen AND ovarian cancer, extracellular matrix AND ovarian cancer, drug resistance AND ovarian cancer".

\section{Study Records}

The relevant clinical, pathological, and pathophysiological data was stored and organized in a word document in Microsoft Word. An independent reviewer (SV) screened the studies using the title and abstracts based on eligibility criteria and relevance to the research question. In case of uncertainty, full articles were reviewed to determine the eligibility for inclusion and framed into this traditional review.

\section{Ethical Issue}

All the data in the following article was collected ethically and legally. All the included studies in this review had full-text links available freely on PubMed.

Inclusion/Exclusion Criteria

Types of patients and conditions: We reviewed the studies that included tissue samples from women of any age who suffered from ovarian cancer. The reviewed study also includes cell lines prepared in the laboratory or obtained from repositories.

Types of outcomes: We searched for the mechanism underlying distant metastasis in ovarian cancer patients, which is the major reason for patients' suffering and decreased survival, the mechanisms responsible for chemotherapeutic resistance to the drugs to improve the sensitivity for a better prognosis and survival.

Types of studies: Mixed human studies relevant to the research question published in peer-reviewed journals were included. There were no geographical restrictions, and articles published only in the English language were included.

\section{Results}

Using the PubMed database, a literature search was done with four keywords, which yielded 9010 studies; after removing 333 duplicates using Mendeley citation manager, 8677 studies were left. On applying inclusion/exclusion criteria, 2781 articles remained, which were screened using title and abstracts. As a result, 2641 studies were excluded. One hundred and forty studies were left. Full-text articles were assessed, which led to the exclusion of 103 due to non-relevance to the research question, and five studies were excluded due to the unavailability of full-text links. In this review, 32 studies were finally included. The number of studies selected with each keyword is collagen (seven studies), ovarian cancer (14 studies), 


\section{Cureus}

extracellular matrix (five studies), drug resistance (six studies), making a total of 32 studies [4-35]. Figure 1 below represents the Preferred Reporting Items for Systematic Review and Meta-Analysis (PRISMA) flow diagram.
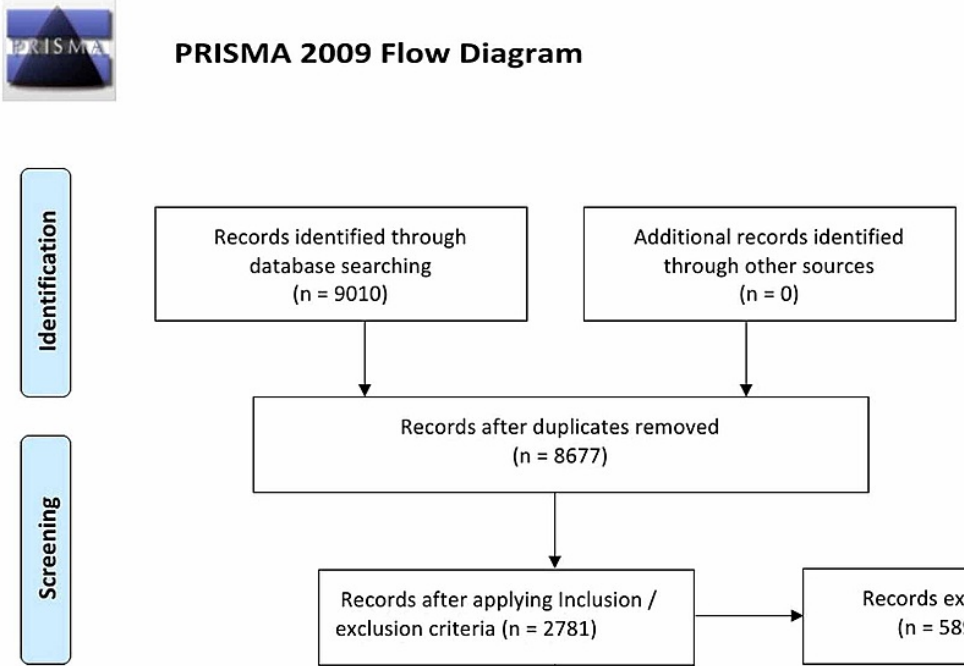

Records after duplicates removed $(n=8677)$
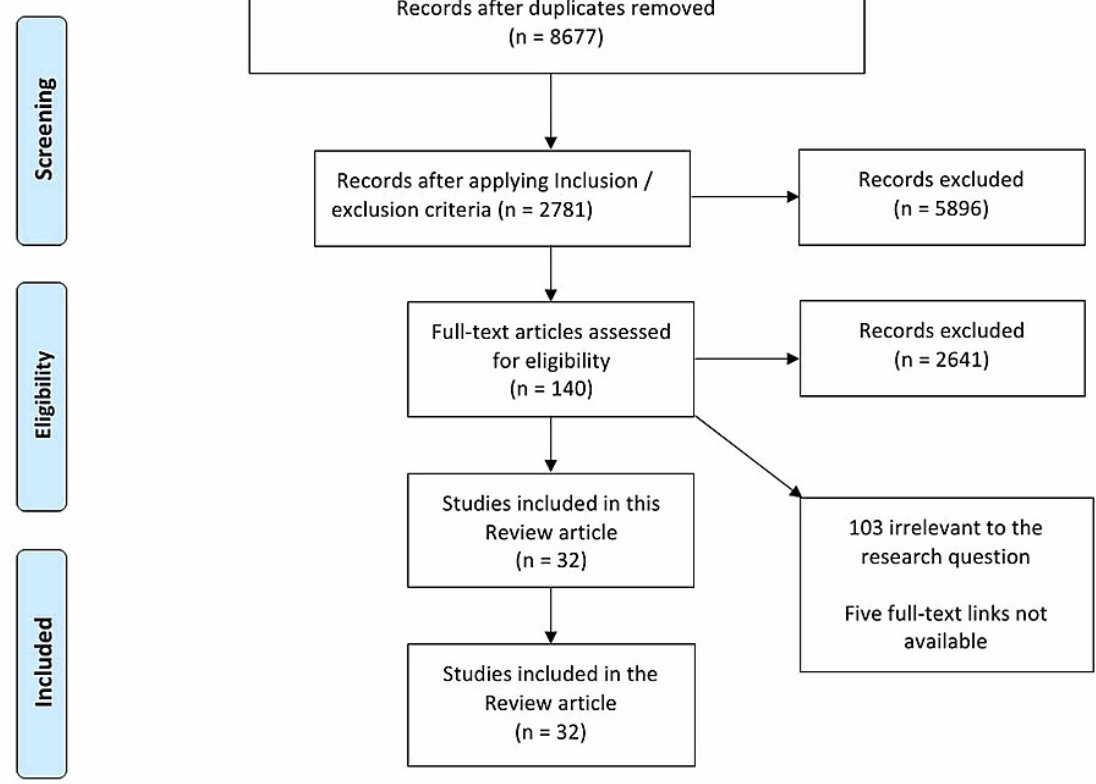

tudies included in the Review article $(n=32)$

FIGURE 1: Preferred Reporting Items for Systematic Review and MetaAnalysis (PRISMA) Flow Diagram

Thirty-two histopathological studies assessing the role of extracellular matrix in ovarian cancer dissemination using a total of 672 female patient's tissue samples, 103 human cell lines, and three murine cell lines were studied. Peritoneal xenografts were used in three studies.

Study characteristics: A total of 32 studies were included, from which information was extracted. A summary of the involved studies is given in Table 1 [4-35].

\begin{tabular}{|l|l|} 
Reference & $\begin{array}{l}\text { Study } \\
\text { characteristics }\end{array}$ \\
& \\
Natarajan & Histopathologica \\
et al. 2019 & study; Animal \\
{$[4]$} & study
\end{tabular}

Patients/tissue samples/cell lines

High grade serous ovarian cancer cell line: OVCAR5, OVCAR8 Human peritoneal mesothelial cell line: LP-9 Primary human mesothelial cells (PHMC): omentum of patients with benign disease Mouse ovarian cancer cell line: ID8

\section{Tests performed}

\section{Gene signature analysis, siRNA} analysis, collagen gels, and confocal microscopy, invasion assay, realtime quantitative polymerase chain reaction (qPCR), Western blotting, Immunohistochemistry, immunofluorescence, second harmonic generation microscopy,
Statistical analysis

It was done with two-way ANOVA and a two-tailed unpaired t-test. Statistical significance of p-value $<0.05$ 


\section{Cureus}

\begin{tabular}{|c|c|c|c|c|}
\hline \multirow[b]{2}{*}{$\begin{array}{l}\text { Yeung et } \\
\text { al. 2019 } \\
\text { [10] }\end{array}$} & \multirow[b]{2}{*}{$\begin{array}{l}\text { Histopathological } \\
\text { study; Animal } \\
\text { study }\end{array}$} & \multirow[b]{2}{*}{ OVCAR432 cells } & \multicolumn{2}{|l|}{ picrosirius red staining } \\
\hline & & & $\begin{array}{l}\text { IVIS bioluminescence fluorescence } \\
\text { imaging system }\end{array}$ & $\begin{array}{l}\text { It was done } \\
\text { with a two- } \\
\text { tailed unpaired } \\
\text { Student's t-test } \\
\text {-the statistical } \\
\text { significance of } \\
\text { p-value }<0.05 \text {. }\end{array}$ \\
\hline $\begin{array}{l}\text { Zhao et al. } \\
2019 \text { [6] }\end{array}$ & $\begin{array}{l}\text { Retrospective } \\
\text { analysis; Animal } \\
\text { study }\end{array}$ & $\begin{array}{l}\text { One hundred and twenty-three patients } \\
\text { with stage IIIC or IV who were previously } \\
\text { taking ACEls or ARBs compared to } 99 \\
\text { patients taking other anti-hypertensives } \\
\text { SKOV3ip1, HeyA8 }\end{array}$ & $\begin{array}{l}\text { Gaussia Luciferase measurement, } \\
\text { extravasation of doxorubicin by } \\
\text { histology, planar-cut method to } \\
\text { measure solid stress, unconfined } \\
\text { compression test to quantify } \\
\text { Young's modulus (stiffness), } \\
\text { lymphatic vessel drainage function } \\
\text { study, histology and } \\
\text { immunohistochemistry, mRNA, } \\
\text { miRNA extraction and array analysis, } \\
\text { transient transfections and reporter } \\
\text { gene assays }\end{array}$ & $\begin{array}{l}\text { It was done } \\
\text { using logistic } \\
\text { regression. It } \\
\text { was done with } \\
\text { the Student's t- } \\
\text { test (two-tailed) } \\
\text { or Mann- } \\
\text { Whitney U test } \\
\text { (two-tailed), } \\
\text { two-sided } \\
\text { Fisher's exact } \\
\text { test. }\end{array}$ \\
\hline $\begin{array}{l}\text { Grither et } \\
\text { al. } 2018 \\
\text { [13] }\end{array}$ & $\begin{array}{l}\text { Histopathological } \\
\text { study }\end{array}$ & $\begin{array}{l}\text { Patient-derived tumor cells-ascites from } \\
\text { patients with ovarian cancer (POV) } \\
\text { 1,9,10,12 Established human ovarian } \\
\text { tumor cell lines-A2780, SKOV3ip1, } \\
\text { OVCAR3, OVCAR5 }\end{array}$ & $\begin{array}{l}\text { Western blot analysis, gelatin } \\
\text { zymography, immunohistochemical } \\
\text { analysis using human tissue } \\
\text { microarrays, Invasion and migration } \\
\text { assays, proliferation assay, real-time } \\
\text { polymerase chain reaction (PCR) } \\
\text { with reverse transcription, } \\
\text { fibronectin cleavage assay, cell } \\
\text { spreading assay, spheroid-induced } \\
\text { mesothelial clearance assay, } \\
\text { survival analysis. }\end{array}$ & $\begin{array}{l}\text { It was done } \\
\text { using a two- } \\
\text { tailed unpaired } \\
\text { Student's t-test } \\
\text { with a } \\
\text { statistical } \\
\text { significance of } \\
\text { p-value }<0.05 \text {. }\end{array}$ \\
\hline $\begin{array}{l}\text { Guo et al. } \\
2017 \text { [12] }\end{array}$ & $\begin{array}{l}\text { Histopathological } \\
\text { study; Animal } \\
\text { study }\end{array}$ & $\begin{array}{l}\text { Tissue samples from } 72 \text { patients of } \\
\text { primary epithelial ovarian cancer (PEOC)- } \\
34 \text { out of } 72 \text { were stage I-II, and the } \\
\text { remaining } 38 \text { patients were stage III-IV. } \\
\text { Ten normal tissue samples. Human } \\
\text { ovarian adenocarcinoma-ascites of a } 64- \\
\text { year-old woman: SKOV3 Human ovarian } \\
\text { clear cell carcinoma: ES2 Ovarian } \\
\text { adenocarcinoma: A2780 Ovarian serous } \\
\text { adenocarcinoma-ascites of Chinese } \\
\text { patients: HO8910 Immortalized ovarian } \\
\text { surface superficial epithelium cell line: } \\
\text { IOSE }\end{array}$ & $\begin{array}{l}\text { Transwell migration and invasion } \\
\text { assays, wound healing assays, cell } \\
\text { adhesion assays, phospho-antibody } \\
\text { microarray, Western blotting, Co- } \\
\text { immunoprecipitation, RNA } \\
\text { extraction, and real-time RT-PCR } \\
\text { assays, immunohistochemistry }\end{array}$ & $\begin{array}{l}\text { It was done } \\
\text { with a double- } \\
\text { sided Student's } \\
\text { t-test and Chi- } \\
\text { square test. } \\
\text { Statistical } \\
\text { significance of } \\
\text { p-value }<0.05 \text {. }\end{array}$ \\
\hline $\begin{array}{l}\text { Fogg et al. } \\
2019 \text { [7] }\end{array}$ & $\begin{array}{l}\text { Histopathological } \\
\text { study }\end{array}$ & $\begin{array}{l}\text { High grade serous ovarian cancer } \\
\text { (HGSOC) cell lines: OVCAR3, OV90, } \\
\text { OVCA433 }\end{array}$ & $\begin{array}{l}\text { Polymerase chain reaction (PCR), } \\
\text { histological analysis, confocal } \\
\text { imaging, and image analysis }\end{array}$ & $\begin{array}{l}\text { Done using } \\
\text { one-way } \\
\text { ANOVA, two- } \\
\text { way ANOVA, or } \\
\text { t-test }\end{array}$ \\
\hline $\begin{array}{l}\text { Chan et al. } \\
2016 \text { [25] }\end{array}$ & $\begin{array}{l}\text { Histopathological } \\
\text { study }\end{array}$ & HEYA8, OVCAR8 & $\begin{array}{l}\text { Scratch wound invasion assay, } \\
\text { scanning electron microscopy } \\
\text { imaging, mRNA/miR isolation, and } \\
\text { quantitative polymerase chain } \\
\text { reaction, predicted miR targeting, } \\
\text { Parallel microfiltration, Microfluidic } \\
\text { device fabrication, and operation } \\
\text { using standard soft lithography, } \\
\text { Flow cytometry. }\end{array}$ & $\begin{array}{l}\text { It was done } \\
\text { separately for } \\
\text { each assay with } \\
\text { a Statistical } \\
\text { significance of } \\
\text { p-value }<0.05 \text {. }\end{array}$ \\
\hline & & & & $\begin{array}{l}\text { It was done } \\
\text { using two-way } \\
\text { ANOVA and }\end{array}$ \\
\hline
\end{tabular}




\section{Cureus} $\begin{array}{|lll|}\text { Samardzija } & \text { Histopathological } & \text { Primary high-grade serous epithelial } \\ \text { et al. } 2016 & \text { study; Animal } & \text { ovarian tumor and normal ovarian tissues } \\ \text { f9] } & \text { study } & \begin{array}{l}\text { from patients. Four established human } \\ \text { epithelial ovarian cancer cell lines: SKOV3, } \\ \end{array} \\ & & \text { OVCAR5, OVCA433, HEY }\end{array}$

Primary human ovarian surface epithelial cell line: MCAS, OVCA432, OVCA433

Choi et al. Histopathological 2016 [31] study HPVE6E7 immortalized OSE cell lines. Normal human ovarian surface epithelial (OSE) cell line: OSE7, OSE9

One hundred and forty paraffin-embedded tissue samples from patients after surgery. Out of 140, 60 were primary epithelial

Liu et al. Histopathological 2019 [21] study ovarian cancer, 30 were borderline ovarian tumors, 30 benign ovarian tumors, 20 normal ovarian tissues. Cell line- RMG-IhFUT

Klymenko et al. 2017 [30]

Histopathological study OvCa432, OvCa433, OvCa429, DOV13 Ovarian adenocarcinoma cell line: line: LP9

Epithelial ovarian cancer cell lines:

Klymenko Histopathological et al. 2017 study; Animal [22] study OvCa433, DOV13 Human peritoneal mesothelial cell line: LP9 Murine epithelial ovarian cancer cell line: ID8 OVCAR3, SKOV3 Human mesothelial cell
Immunofluorescence analysis, RNA extraction and real-time PCR, assay, flow cytometric analysis, adhesion assay, gelatin zymography

Immunofluorescence microscopy, immunohistochemical staining of tissue samples, gene expression profiling and network analysis, quantitative real-time reverse transcription PCR, Western blot analysis

Reverse transcription-quantitative polymerase chain reaction (RTqPCR) analysis, Western blot analysis, co-immunoprecipitation assay, Confocal laser scanning microscopy, Cell adhesion assay, immunohistochemical staining, immunocytochemical staining

Quantitative polymerase chain reaction of cDNA arrays, Western blot analysis, dual-label immunofluorescence microscopy (DLIF), MCA and tissue scanning electron microscopy (SEM), transmission electron microscopy (TEM), cell proliferation assay, cell migration assay, Matrigel invasion assay, cell-to-collagen adhesion assay, cell-to-mesothelium adhesion assay, cell-to-peritoneum adhesion assay.

Cell adhesion assay, mesothelial clearance assay, scanning electron microscopy (SEM)

Immunohistochemistry, RNA extraction, and quantitative PCR, DNA methylation analysis, chromatin immunoprecipitation assay, wound healing assay, invasion assay, colony formation in soft agar, cell cytotoxicity assay, flow cytometric detection of apoptosis Western blotting, sphere forming

Dunnett's multiple comparison test with a Statistical significance of p-value $<0.05$.

It was done with ANOVA and a twotailed t-test. Statistical significance of p-value $<0.05$.

It was done with Student's t-test, chisquare test, one-way analysis of variance with LSD or

Bonferroni posthoc test, and Kaplan-

Meier curves.

Statistical significance of p-value $<0.05$.

Done using Student's t-test

\section{It was done} using the twosided MannWhitney U test with a

Statistical significance of p-value $<0.05$.

It was done using a twotailed Student's

Human ovarian cancer cell line: SKOV3, HO-8910 Immortalized ovarian epithelial cell line: IOSE386
Deng et al. Histopathologica 2017 [34] study t-test and

Pearson's

correlation test

with a

Statistical significance of $p$-value $<0.05$.

Done using

Pearson's test, 


\section{Cureus}

\begin{tabular}{|c|c|c|c|c|}
\hline $\begin{array}{l}\text { Ye et al. } \\
2016[26]\end{array}$ & $\begin{array}{l}\text { Histopathological } \\
\text { study }\end{array}$ & $\begin{array}{l}\text { Eighty-three tissue samples of human } \\
\text { ovarian cancer with } 18 \text { normal ovarian } \\
\text { tissue samples as controls Human ovarian } \\
\text { cancer cell lines: SKOV3, ES2, CAOV3, } \\
\text { HEY, COV318 }\end{array}$ & $\begin{array}{l}\text { Immunohistochemical staining, RNA } \\
\text { interference-based gene silencing } \\
\text { experiment, Western blot analysis, } \\
\text { quantitative real-time PCR, cell } \\
\text { viability assay, in-vitro migration, } \\
\text { and invasion assay }\end{array}$ & $\begin{array}{l}\text { Kaplan-Meier } \\
\text { method, } \\
\text { Student's t-test } \\
\text { with a } \\
\text { statistical } \\
\text { significance of } \\
\text { p-value }<0.05 \text {. }\end{array}$ \\
\hline $\begin{array}{l}\text { Shen et al. } \\
2016[17]\end{array}$ & $\begin{array}{l}\text { Histopathological } \\
\text { study }\end{array}$ & $\begin{array}{l}\text { Tissue samples of } 102 \text { patients with } \\
\text { epithelial ovarian cancer Epithelial ovarian } \\
\text { cancer cell lines: OVCAR3, SKOV3 }\end{array}$ & $\begin{array}{l}\text { Immunohistochemistry, } \\
\text { immunofluorescence assay, } \\
\text { immunoprecipitation assay, Western } \\
\text { blot analysis, cell migration assay, } \\
\text { quantitative qPCR }\end{array}$ & $\begin{array}{l}\text { It was done } \\
\text { using an } \\
\text { unpaired } \\
\text { Student's t-test } \\
\text { with a } \\
\text { statistical } \\
\text { significance of } \\
\text { p-value }<0.05 \text {. }\end{array}$ \\
\hline $\begin{array}{l}\text { Yin et al. } \\
2016[18]\end{array}$ & $\begin{array}{l}\text { Histopathological } \\
\text { study }\end{array}$ & $\begin{array}{l}\text { Human ovarian cancer cell line: SKOV-3, } \\
\text { HO-8910 }\end{array}$ & $\begin{array}{l}\text { Real-time PCR, Western blot, } \\
\text { enzyme-linked immunosorbent } \\
\text { assay (ELISA), RNA interference, cell } \\
\text { adhesion assay, cell viability assay }\end{array}$ & $\begin{array}{l}\text { It was done } \\
\text { using ANOVA } \\
\text { with a } \\
\text { statistical } \\
\text { significance of } \\
\text { p-value }<0.05 \text {. }\end{array}$ \\
\hline $\begin{array}{l}\text { Klymenko } \\
\text { et al. } 2018 \\
\text { [29] }\end{array}$ & $\begin{array}{l}\text { Histopathological } \\
\text { study }\end{array}$ & $\begin{array}{l}\text { Epithelial ovarian cancer (EOC) cell lines: } \\
\text { OvCa429, OvCa433, DOV13, SKOV3 }\end{array}$ & $\begin{array}{l}\text { Analysis of proliferation, Western } \\
\text { blot analysis, RNA extraction, and } \\
\text { qPCR, scanning electron } \\
\text { microscopy (SEM) }\end{array}$ & $\begin{array}{l}\text { It was done } \\
\text { using the two- } \\
\text { sided Mann- } \\
\text { Whitney U test } \\
\text { with a } \\
\text { statistical } \\
\text { significance of } \\
\text { p-value }<0.05 \text {. }\end{array}$ \\
\hline $\begin{array}{l}\text { Bruney et } \\
\text { al. } 2016 \\
\text { [16] }\end{array}$ & $\begin{array}{l}\text { Histopathological } \\
\text { study }\end{array}$ & $\begin{array}{l}\text { Ovarian cancer cell lines: DOV13, } \\
\text { OVCA433, SKOV3, ES2 Human peritoneal } \\
\text { mesothelial cell line: LP9 }\end{array}$ & $\begin{array}{l}\text { Western blotting and } \\
\text { immunoprecipitation, quantitative } \\
\text { real-time PCR (qPCR), } \\
\text { Immunohistochemistry, } \\
\text { immunofluorescence, adhesion, and } \\
\text { invasion assay }\end{array}$ & $\begin{array}{l}\text { Done using } \\
\text { Student's t- } \\
\text { test, Mann- } \\
\text { Whitney U test, } \\
\text { Kruskal-Wallis } \\
\text { test with a } \\
\text { Statistical } \\
\text { significance of } \\
\text { p-value }<0.05 \text {. }\end{array}$ \\
\hline $\begin{array}{l}\text { Price et al. } \\
2020[27]\end{array}$ & $\begin{array}{l}\text { Histopathological } \\
\text { study; Animal } \\
\text { study }\end{array}$ & $\begin{array}{l}\text { Human ovarian cancer cell lines: OVCAR3, } \\
\text { OVSAHO, OVCA429, A2780, SKOV3-IP1 } \\
\text { Mouse cell line: ID8 IP2 }\end{array}$ & $\begin{array}{l}\text { Immunoblotting, RT-PCR, ID8 IP2 in } \\
\text { vivo modeling Histology, flow } \\
\text { cytometry, adhesion to ECM, } \\
\text { migration scratch/wound assay, } \\
\text { invasion assay, proliferation assay, }\end{array}$ & $\begin{array}{l}\text { Done using } \\
\text { two-tailed } \\
\text { Welsh's t-test, } \\
\text { Mental-Cox and } \\
\text { Gehan- } \\
\text { Breslow- } \\
\text { Wilcoxon test } \\
\text { with a } \\
\text { statistical } \\
\text { significance of } \\
\text { p-value }<0.05 \text {. }\end{array}$ \\
\hline \multirow[t]{2}{*}{$\begin{array}{l}\text { Bruney et } \\
\text { al. } 2014 \\
{[20]}\end{array}$} & \multirow[t]{2}{*}{$\begin{array}{l}\text { Histopathological } \\
\text { study }\end{array}$} & \multirow[t]{2}{*}{$\begin{array}{l}\text { Ovarian cancer cell line: OVCA433 Ovarian } \\
\text { adenocarcinoma cell line: OVCAR3 Human } \\
\text { mesothelial cell line: LP9 }\end{array}$} & $\begin{array}{l}\text { Immunohistochemistry, } \\
\text { immunofluorescence, quantitative } \\
\text { real-time PCR (qPCR), florescence- } \\
\text { activated cell sorting (FACS) } \\
\text { analysis, enzyme-linked } \\
\text { immunosorbent assay, mesothelial } \\
\text { cell adhesion assay, meso-mimetic } \\
\text { invasion assay, adhesion to } \\
\text { peritoneal explant }\end{array}$ & $\begin{array}{l}\text { Done using } \\
\text { Student's t-test }\end{array}$ \\
\hline & & & $\begin{array}{l}\text { Quantitative reverse transcription } \\
\text { PCR (qRT-PCR), cell proliferation }\end{array}$ & $\begin{array}{l}\text { It was done } \\
\text { using a t-test } \\
\text { and analysis of }\end{array}$ \\
\hline
\end{tabular}




\section{Cureus} $\begin{array}{lll}\text { Li et al. } & \text { Histopathological } & \text { Human ovarian cancer epithelial cell line: } \\ 2020[23] & \text { study } & \text { OVCAR3 Human normal ovarian epithelia }\end{array}$ cell line: IOSE80

Cheon et Histopathological Snap-frozen and paraffin-embedded al. 2014 study; Animal [15] study patient samples. Cancer cell lines: OVCAR3, A2780 Normal cell lines: TRS3

Flate and Stalvey 2014 [28] Histopathological study

Cisplatin sensitive cell line: OV2008 Cisplatin resistant cell line: C13

Dai et al.

Histopathological 2015 [8] study

Human ovarian cancer cell line: OVCAR-3

Sun et al. Histopathological Highly metastatic human ovarian cancer 2015 [19] study cell line: HO-8910PM

Vallen et al. 2014 [33]

Histopathological study

Tissue samples from 25 patients of serous subtype of ovarian cancer Human ovarian cancer cell line: SKOV3
Gurler et al. 2015 [11]
Normal and pathologic ovarian tissue Histopathological samples: OV2161, OV2087, OV808 Human study
Histopathological study

3, OAW28, Kuramochi, OVSAHO, OVKATE

activity assay, flow cytometry, transwell cell migration and invasion assay, double luciferase activity assay, Western blot

Microarray data analyses, validation of the 10-gene signature, RNA isolation and RT- qPCR analysis, molecular pathway analysis, in situ hybridization, immunohistochemistry

Wound healing assay, migration assay, Western blot analysis, microarray

RT-PCR analysis, analysis of cell proliferation using MTT assay, cell migration assessment, cell invasion assay, Western blot variance

(ANOVA) with a statistical significance of p-value $<0.05$

It was done using an unpaired t-test with a statistical significance of $\mathrm{p}$-value $<0.05$.

It was done using one-way ANOVA, Tukey, and LSD post hoc tests with a statistical significance of p-value $<0.05$.

It was done using an independent sample t-test and Post-hoc Turkey-test with a statistical significance of p-value $<0.05$.

Three-dimensional type I collagen invasion and degradation assay, RTPCR analysis, Western blotting analysis, cell surface biotinylation, fluorescent immunocytochemistry, CAM invasion assay.

Immunohistochemistry, reverse phase-high performance liquid chromatography (RP-HPLC) disaccharide analysis, twodimensional scratch assay, hanging drop experiment, cell migration assay

Adhesion, migration and invasion assays, microscopy, Dunn chemotactic migration assay, spheroid formation, and collagen embedding, two-dimensional immunofluorescence (IF), threedimensional Immunofluorescence and Invasion assay, RhoA GTPase G-LISA activation assay,

Immunohistochemistry, immunofluorescence staining, subcellular fractionation, Western blot, transient transfections, paclitaxel treatment, cell survival, and clonogenic assay
N/A using a onetailed Student's t-test with a statistical significance of p-value $<0.05$.

It was done with the Student's t-test and the statistical significance of $\mathrm{p}$-value $<0.05$.

It was done
It was done 


\section{Cureus}

\begin{tabular}{|c|c|c|c|c|}
\hline $\begin{array}{l}\text { Triulzi et } \\
\text { al. 2014 } \\
\text { [35] }\end{array}$ & $\begin{array}{l}\text { Histopathological } \\
\text { study; Animal } \\
\text { study }\end{array}$ & Human ovarian cancer cell line: SKOV3 & $\begin{array}{l}\text { Proliferation and doxorubicin } \\
\text { response assays, Western blotting, } \\
\text { confocal microscopy, } \\
\text { Immunohistochemical (IHC) } \\
\text { analyses, RNA extraction, and } \\
\text { quantitative real-time PCR }\end{array}$ & $\begin{array}{l}\text { using a t-test, } \\
\text { chi-square test, } \\
\text { two-tailed } \\
\text { unpaired } \\
\text { student's t-test } \\
\text { with a } \\
\text { statistical } \\
\text { significance of } \\
\text { p-value }<0.05 \text {. }\end{array}$ \\
\hline $\begin{array}{l}\text { Wahab et } \\
\text { al. 2020 } \\
\text { [24] }\end{array}$ & $\begin{array}{l}\text { Histopathological } \\
\text { study }\end{array}$ & $\begin{array}{l}\text { Twenty-four unmatched snap-frozen } \\
\text { ovarian tissue samples from patients } \\
\text { consisting of } 11 \text { serous ovarian cancer } \\
\text { and } 13 \text { normal ovarian tissues Ovarian } \\
\text { adenocarcinoma cell lines: Caov3 and } \\
\text { ovarian adenocarcinoma, ascites cell line: } \\
\text { SKOV3 }\end{array}$ & $\begin{array}{l}\text { MicroRNA expression profiling and } \\
\text { validation, bioinformatics analysis, } \\
\text { quantitative real-time PCR, cell } \\
\text { viability, migration, and invasion } \\
\text { assays }\end{array}$ & $\begin{array}{l}\text { It was done } \\
\text { using the } \\
\text { Kruskal-Wallis } \\
\text { and LIMMA } \\
\text { statistical tests, } \\
\text { Student's t-test } \\
\text { with a } \\
\text { statistical } \\
\text { significance of } \\
\text { p-value }<0.05 \text {. }\end{array}$ \\
\hline $\begin{array}{l}\text { Minopoli et } \\
\text { al. } 2019 \\
{[14]}\end{array}$ & $\begin{array}{l}\text { Histopathological } \\
\text { study }\end{array}$ & $\begin{array}{l}\text { Tissue samples of } 42 \text { patients with } \\
\text { different subtypes of epithelial ovarian } \\
\text { cancer Human ovarian carcinoma cell line: } \\
\text { SKOV-3, A2780 }\end{array}$ & $\begin{array}{l}\text { Tissue microarray building, } \\
\text { Immunohistochemistry, Flow } \\
\text { cytometry, the culture of mesothelial } \\
\text { cells, Western blot, adhesion of } \\
\text { epithelial ovarian cancer (EOC) cells } \\
\text { onto extracellular matrix proteins, } \\
\text { adhesion and invasion assay, } \\
\text { fluorescence microscopy, ligand } \\
\text { binding assay. }\end{array}$ & $\begin{array}{l}\text { Done using } \\
\text { one-way } \\
\text { ANOVA and } \\
\text { post hoc } \\
\text { Dunnett t-test, } \\
\text { Pearson's chi- } \\
\text { square test with } \\
\text { a statistical } \\
\text { significance of } \\
\text { p-value }<0.05 \text {. }\end{array}$ \\
\hline $\begin{array}{l}\text { Zhang et } \\
\text { al. } 2019 \text { [5] }\end{array}$ & $\begin{array}{l}\text { Histopathological } \\
\text { study }\end{array}$ & $\begin{array}{l}\text { Ninety-one formalin-fixed and paraffin- } \\
\text { embedded tissue samples from patients } \\
\text { with high-grade serous adenocarcinoma } \\
\text { Ovarian cancer cell line: A2780 }\end{array}$ & $\begin{array}{l}\text { Immunohistochemistry, Western blot } \\
\text { analysis, RT-PCR, transwell } \\
\text { migration assay }\end{array}$ & $\begin{array}{l}\text { Done with } \\
\text { unpaired } \\
\text { Student's t- } \\
\text { test, Pearson's } \\
\text { correlation } \\
\text { analysis. } \\
\text { Statistical } \\
\text { significance of } \\
\text { p-value }<0.05 \text {. }\end{array}$ \\
\hline
\end{tabular}

\section{TABLE 1: Synopsis of Involved Studies}

ACEls: angiotensin-converting enzyme inhibitors, ARBs: angiotensin receptor blockers, ANOVA: analysis of variance, MTT: 3-[4, 5-dimethylthiazol-2yl]-2, 5-diphenyl tetrazolium bromide, CAM: chorioallantoic membrane, RT-PCR: real-time polymerase chain reaction

\section{Discussion}

Early metastasis and late presentation of the patients with metastasis to the peritoneum, causing ascites, is a distinct feature of ovarian cancer. Initial response to chemotherapy and later development of resistance is another feature of ovarian cancer. The molecular mechanism underlying these processes may be targeted to prevent tumor spread. Figure 2 shows a schematic view of the pathophysiology of ovarian cancer metastasis $[4,5,7,9,12-14,16,18-23,26-28]$. 


\section{Cureus}

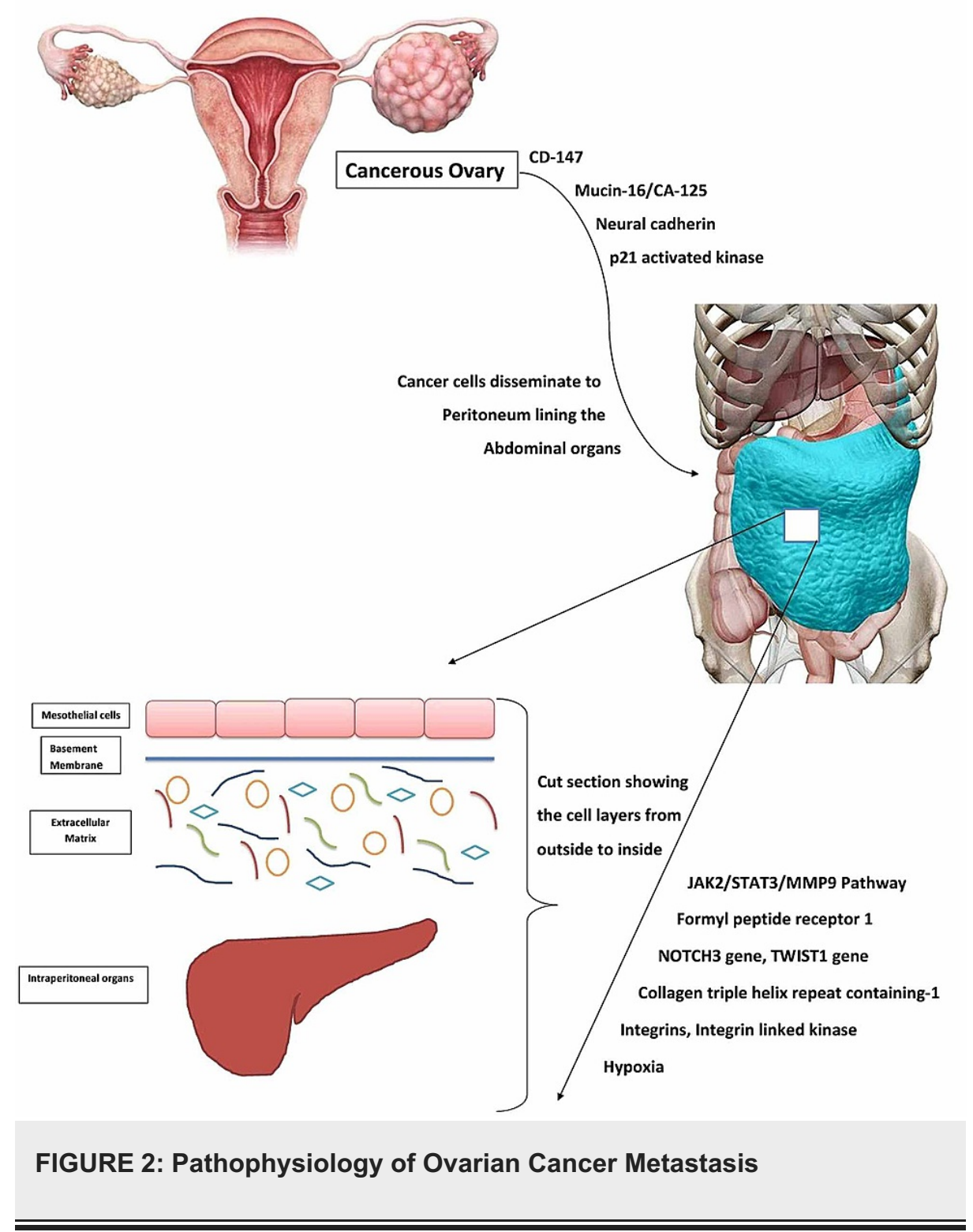

Hypoxic Tumor Microenvironment and Matrix Metalloproteinases

Hypoxia has been shown to promote ovarian cancer cell invasion. Natarajan et al. showed enhanced expression of proline-lysine hydroxylases and lysyl oxidase in mesothelial cells leading to increased collagen deposition and increased collagen cross-linking respectively in the hypoxic tumor microenvironment, and this collagen remodeling subsequently leads to tumor invasion as hypoxia-inducible factor- 1 and factor- 2 (HIF-1 and 2) gets stabilized [4]. Zhang et al. showed increased mRNA and protein levels of HIF- $\alpha$ and matrix metalloproteinase-13 (MMP-13) in response to hypoxia, both of which decreased after transfection with small interfering RNA (siRNA) for HIF $\alpha$. Matrix metalloproteinases are enzymes responsible for degrading ECM proteins, making tumor cells invade [5]. In contrast, Sun et al. showed hypoxia-induced ovarian cancer cell invasion using hydroxyproline levels to detect collagen degradation by membrane-type 1-matrix metalloproteinase (MT1-MMP). They also showed increased mRNA and protein levels of MT1-MMP in response to hypoxia, which aids in invasions like Zhang et al. Hypoxia also causes increased Snail (a zincfinger transcription factor) expression, which leads to enhanced expression of MT1-MMP responsible for three-dimensional collagen invasion [19].

The glycoproteins expressed on the surface of tumor cells mediate cell adhesion and subsequent invasion. CD147, a highly glycosylated protein on the tumor cell surface, having Lewis antigen on its surface promotes CD147 mediated tumor cell adhesion and expression of matrix metalloproteinase-2 (MMP-2). CD147 and Lewis-Y antigen expression was associated with a higher adhesive ability to ECM proteins collagen and laminin, higher tumor grade, metastasis to lymph nodes, and decreased survival [21]. Another glycoprotein, Mucin 16 (MUC 16)/cancer antigen (CA-125), expressed on tumor cells binds mesothelin of mesothelial cells of the peritoneum, which is the initial event in tumor adhesion and spreading across the ECM. Matrix metalloproteinases (MT1-MMP, MMP-14) were seen catalyzing the degradation of MUC-16/CA-125, 
The cadherin composition and expression of matrix metalloproteinases (MMP) govern collagen matrix invasion and peritoneal metastasis. Klymenko et al. highlighted neural cadherin's (Ncad) presence on MCA to have significant depth penetration, rapid lateral migration through the mesothelium before disrupting the basement membrane to invade ECM compared to epithelial cadherin (Ecad) expressing cells. Inhibition of MMP showed decreased invasion of cancer cells [22]. Integrins play a role in the adhesion of tumor cells to ECM proteins. Oct4A is a transcription factor, suppression of which is associated with decreased expression of integrin $\beta 1, \alpha 5$, and $\alpha 2$ subunits leading to diminished adhesion of tumor cells to collagen and fibronectin, decreased levels of MMP-2, and certain markers. Upregulation of Oct4A was linked to the formation of stable, highly compact MCA [9]. Another study showing the formation of more cohesive MCA was coupled with the expression of integrin-linked kinase (ILK), co-expressed with MT1-MMP. ILK catalyzes the phosphorylation of cytoplasmic tails of MMP, which leads to the formation of stable MCA, which causes metastasis. ILK also regulates Integrin-mediated cell adhesion causing mesothelial cells to retract, uncovering the ECM [16]. Table 2 below highlights the objectives and potential therapeutic targets of the included studies $[4,5,9,16,19-22]$.

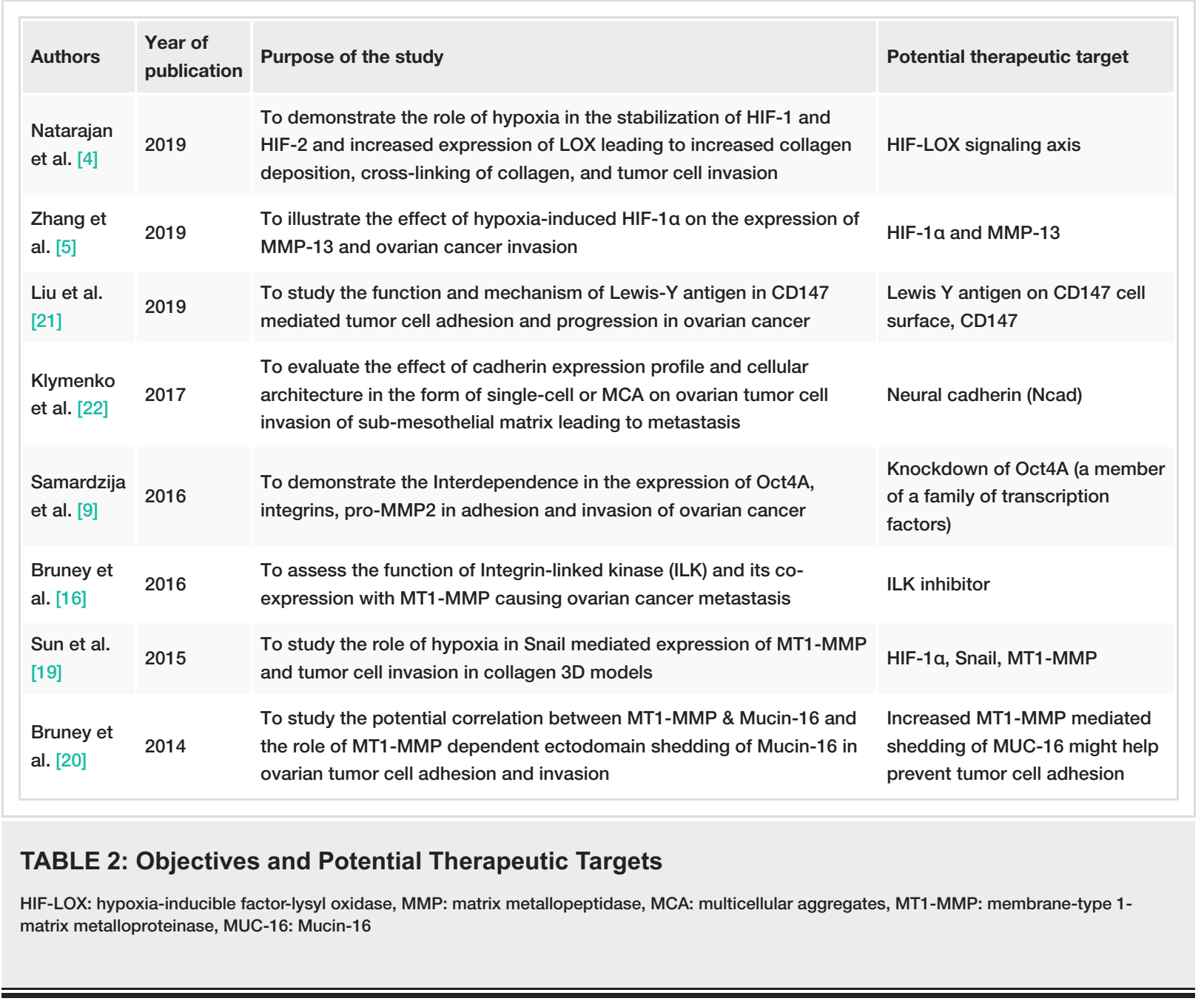

The Theatrical Role of Genetics

MicroRNA expression is a well-known cause of improved survival in ovarian cancer patients. Li et al. illustrated miR-30b-3p targeting its gene collagen triple helix repeat containing 1 (CTHRC1) at 3'UTR region, decreasing the protein expression of CTHRC1, which hinders epithelial to mesenchymal transformation in ovarian cancer cells. miR-30b-3p is an anticancer gene, and its overexpression inhibits migration and invasion of ovarian cancer cells, suppresses proliferation, promotes apoptosis [23]. Wahab et al. discovered 48 MicroRNAs acting on their targeted genes inhibiting ovarian cancer cell migration and invasion. MicroRNAs were shown to correlate with ovarian cancer histological subtype, tumor stage, chemoresistance to drugs, cancer recurrence, and survival [24]. Another study showed the role of tumor suppressor MicroRNAs in the invasion of ovarian cancer. MicroRNA overexpression leads to increased filamentous actin (F-actin) levels, which decreases the invasive potential of cancer cells through collagen matrices. Increased cell size and reduced deformability were seen with tumor suppressor MicroRNA transfection, making it 


\section{Cureus}

useful as bigger cells have lesser invasive potential, and less deformable cells take longer to transit [25].

CTHRC1 is a cancer-related gene involved in certain signaling molecules' phosphorylation, enhancing the migration and invasion of ovarian cancer. A study by Ye et al. observed decreased phosphorylation of epidermal growth factor receptor (EGFR), extracellular signal-regulated kinase 1/2 (ERK1/2), protein kinase (AKT), and reduced migration and invasion of ovarian cancer cells on silencing the CTHRC1. They also observed that the EGFR inhibitors blocked the effect of CTHRC1. Hence it was suggested that CTHRC1, by activating EGFR signaling, promotes metastasis in ovarian cancer, which is mediated through ERK1/2, PI3K/AKT [26]. CTHRC1 was also found to be increasing the expression of Integrin $\beta 3$ and phosphorylating focal adhesion kinase (FAK), which led to invasion and migration of ovarian cancer cells, enhanced adhesion to ECM proteins, peritoneal and lymph node metastasis [12].

Cheon et al.'s gene signature analysis identified 10 collagen remodeling genes regulated by transforming growth factor- $\beta$ (TGF $\beta 1$ ) signaling. COL11A1 was among the genes discovered, which showed significantly higher expression in metastatic tumors than primary tumors. These genes were found to promote metastasis and decreased survival [15]. Identification of downstream targets upon activation of NOTCH3 Intracellular domain (NOTCH3IC) showed induction of genes encoding ECM proteins and adhesion molecules. Collagen and Integrin genes were identified to promote cancer cell attachment to the peritoneum, causing ascites leading to poor survival [27]. An epithelial to mesenchymal transcription factor TWIST1 induces the expression of a mesenchymal gene discoidin domain receptor 2 (DDR2), which recognizes collagen as its ligand. DDR2 controls ECM remodeling enzymes' expression, which could lead to enhanced migration and invasion of tumor cells, cleavage of fibronectin, mesothelial cell clearance facilitating metastasis, and decreased survival [13]. Table 3 below highlights the objectives and potential therapeutic targets of the included studies $[12,13,15,23-27]$.

\begin{tabular}{|c|c|c|c|}
\hline Authors & $\begin{array}{l}\text { Year of } \\
\text { publication }\end{array}$ & Purpose of the study & $\begin{array}{l}\text { Potential therapeutic } \\
\text { target }\end{array}$ \\
\hline $\begin{array}{l}\text { Li et al. } \\
{[23]}\end{array}$ & 2020 & $\begin{array}{l}\text { To investigate the role of anticancer gene miR-30b-3p on the biological activity of } \\
\text { ovarian cancer cells and its association with the CTHRC1 gene }\end{array}$ & $\begin{array}{l}\text { MicroRNA miR-30 } \\
\text { family }\end{array}$ \\
\hline $\begin{array}{l}\text { Wahab } \\
\text { et al. } \\
\text { [24] }\end{array}$ & 2020 & $\begin{array}{l}\text { To study the effect of differential expression of microRNAs and their target genes in } \\
\text { ovarian cancer growth, migration, and invasion }\end{array}$ & MicroRNA \\
\hline $\begin{array}{l}\text { Price et } \\
\text { al. [27] }\end{array}$ & 2020 & $\begin{array}{l}\text { To assess the effect of NOTCH3 signaling on tumor cell adhesion to the peritoneum, } \\
\text { tumor cell proliferation, and patient survival }\end{array}$ & NOTCH3 \\
\hline $\begin{array}{l}\text { Grither } \\
\text { et al. } \\
\text { [13] }\end{array}$ & 2018 & $\begin{array}{l}\text { To study the TWIST1 induced expression of DDR2 leading to mesothelial cell } \\
\text { clearance and tumor cell invasion }\end{array}$ & DDR2 \\
\hline $\begin{array}{l}\text { Guo et } \\
\text { al. [12] }\end{array}$ & 2017 & $\begin{array}{l}\text { To investigate the role of CTHRC1 in ovarian cancer cell migration, invasion, and } \\
\text { adhesion to vitronectin, peritoneal metastasis, and metastasis to distant organs }\end{array}$ & $\begin{array}{l}\text { CTHRC1, Integrin } \\
\text { B3/FAK signaling }\end{array}$ \\
\hline $\begin{array}{l}\text { Chan et } \\
\text { al. [25] }\end{array}$ & 2016 & $\begin{array}{l}\text { To elucidate the mechanistic role of tumor suppressor microRNAs in ovarian cancer } \\
\text { invasion and cancer cell physical properties }\end{array}$ & MicroRNA \\
\hline $\begin{array}{l}\text { Ye et al. } \\
{[26]}\end{array}$ & 2016 & $\begin{array}{l}\text { To study the effect of CTHRC1 induced EGFR signaling on ovarian cancer cell } \\
\text { migration and invasion }\end{array}$ & CTHRC1 \\
\hline $\begin{array}{l}\text { Cheon } \\
\text { et al. } \\
{[15]}\end{array}$ & 2014 & $\begin{array}{l}\text { To identify collagen remodeling genes regulated by TGF } \beta \text { signaling, promoting } \\
\text { metastasis and leading to poor clinical outcome }\end{array}$ & $\begin{array}{l}\text { Collagen remodeling } \\
\text { genes, e.g., COL11A1 }\end{array}$ \\
\hline
\end{tabular}

\section{TABLE 3: Objectives and Potential Therapeutic Targets}

CTHRC1: collagen triple helix repeat containing 1, DDR2: discoidin domain receptor 2, EGFR: epidermal growth factor receptor, TGFß: transforming growth factor- $\beta$ 
In addition to receptors, enzymes also promote ovarian cancer proliferation and dissemination. Shen et al. showed how histone deacetylase-4 (HDCA-4) enhanced cancer cell proliferation. Higher expression of HDCA-4 corresponds to a higher stage of cancer. HDCA-4 gets co-localized in the nucleus and PP1 in response to collagen matrices, which leads to altered transcription and translation of p21, promoting proliferation and migration of cancer cells [17]. Another study by Dai et al. showed mitogen-activated protein kinase 7 (MAPK7) associated with ovarian cancer cell proliferation, migration, and invasion. Type II collagen expression also increased with MAPK7 overexpression [8]. Flate and Stalvey showed that tumor cells interact with ECM proteins like collagen and fibronectin, which affects cell migration and invasion. They also highlighted p21 activated kinase (PAK) mediating the process of migration of cancer cells [28].

Cancer cells form spheroids by making cell-to-cell contact, affecting ovarian cancer cell behavior in the tumor microenvironment. Fogg et al., in their study, identified alternatively activated macrophages (AAM) in the ascitic fluid to be secreting certain soluble factors, e.g., Fms related tyrosine kinase 3 (FLT3), interleukin-2 (IL-2), interleukin-8 (IL-8), leptin, heparin binding-epidermal growth factor-like factor (HBEGF). These factors were acting through a common pathway of JAK2/STAT3 activation, inducing MMP-9. This pathway leads to disaggregation of spheroids making single cells spread across the ECM [7]. Klymenko et al. showed increased lateral dispersion of spheroids (aka MCA) in response to ascites-induced compression. They also studied the effect of compression on MCA gene expression [29]. The expression of cadherins also influences metastatic success. Ncad+ cells form highly compact stable MCA, whereas Ecad+ cells tend to form loosely adherent cell clusters. Acquisition of Ncad by Ecad+ cells, making a hybrid increased migration, adhesion to mesothelial cells, invasion of ECM developing into secondary metastatic lesions [30]. Another study delineating the role of Cadherins showed high levels of E-cadherin in cancerous cysts. They also showed that E-cadherin repression led to cyst disruption and inhibited collective cancer cell migration. Hence, it was suggested that E-cadherin is important for cancer cells to migrate collectively in collagen matrices [31]. A study by Pettee et al. discovered a Rho GTPase effector mDia formin, which controls F-actin assembly required for cell-cell junction and tight spheroid formation. Inhibiting mDia led to the transition of cells acquiring an amoeboid configuration and invasive single cell dissemination. Rhoassociated protein kinase (ROCK) is another Rho effector. Inhibiting both mDia and ROCK completely blocked invasion, which suggested that single-cell dissemination on inhibiting mDia is ROCK dependent [32]. Vallen et al. showed the overexpression of a 4,6 sulfated glycosaminoglycan (chondroitin sulfate E aka CSE) enhanced the adhesiveness between cells, which is seen in the spheroid formation and cancer metastasis [33]. Table 4 below highlights the objectives and potential therapeutic targets of the included studies [7,8,14,17,28-33]. 


\section{Cureus}

\begin{tabular}{|c|c|c|c|}
\hline Authors & $\begin{array}{l}\text { Year of } \\
\text { publication }\end{array}$ & Purpose of the study & $\begin{array}{l}\text { Potential therapeutic } \\
\text { target }\end{array}$ \\
\hline $\begin{array}{l}\text { Minopoli et } \\
\text { al. [14] }\end{array}$ & 2019 & $\begin{array}{l}\text { To illustrate the role of FPR1 in adhesion to mesothelial cell layer and vitronectin } \\
\text { leading to invasion of ovarian cancer cells }\end{array}$ & $\begin{array}{l}\text { Inhibition of uPAR- } \\
\text { FPR1 interaction }\end{array}$ \\
\hline $\begin{array}{l}\text { Fogg et al. } \\
{[7]}\end{array}$ & 2019 & $\begin{array}{l}\text { To identify the role of soluble factors secreted from AAM in spheroid spreading } \\
\text { across the ECM }\end{array}$ & $\begin{array}{l}\text { JAK/STAT3/MMP-9 } \\
\text { pathway }\end{array}$ \\
\hline $\begin{array}{l}\text { Klymenko } \\
\text { et al. [29] }\end{array}$ & 2018 & $\begin{array}{l}\text { To study the effect of ascites induced compression on invasion, lateral } \\
\text { dispersion, the proliferation of cells of MCA }\end{array}$ & $\begin{array}{l}\text { Drugs to eliminate } \\
\text { ascites }\end{array}$ \\
\hline $\begin{array}{l}\text { Klymenko } \\
\text { et al. [30] }\end{array}$ & 2017 & $\begin{array}{l}\text { To study the diverse cadherin expression affecting the behavior of ovarian } \\
\text { cancer MCA and single-cell dissemination }\end{array}$ & Cadherin \\
\hline $\begin{array}{l}\text { Choi et al. } \\
\text { [31] }\end{array}$ & 2016 & $\begin{array}{l}\text { To assess the effect of loss of E-cadherin on inclusion cyst formation and } \\
\text { collective cancer cell migration }\end{array}$ & $\begin{array}{l}\text { Cadherin, miR-200, } \\
\text { TGF } \beta \text { signaling }\end{array}$ \\
\hline $\begin{array}{l}\text { Shen et al. } \\
{[17]}\end{array}$ & 2016 & $\begin{array}{l}\text { To elucidate the mechanism of action of HDAC4 on ovarian cancer cell } \\
\text { proliferation and migration via repression of } \mathrm{p} 21\end{array}$ & Nuclear HDAC4 \\
\hline Dai et al. [8] & 2015 & $\begin{array}{l}\text { To study the role of MAPK7 on ovarian cancer cell proliferation, migration, } \\
\text { invasion }\end{array}$ & Inhibition of MAPK7 \\
\hline $\begin{array}{l}\text { Flate and } \\
\text { Stalvey [28] }\end{array}$ & 2014 & $\begin{array}{l}\text { To demonstrate the role of PAK2 mediating the ovarian cancer cells interaction } \\
\text { with collagen type I and fibronectin, causing metastasis }\end{array}$ & Inhibition of PAK2 \\
\hline $\begin{array}{l}\text { Pettee et al. } \\
\text { [32] }\end{array}$ & 2014 & $\begin{array}{l}\text { To study the effect of multiple Rho-GTPase effectors (mDia2, ROCK) on ovarian } \\
\text { cancer cell invasion }\end{array}$ & $\begin{array}{l}\text { mDia2/ROCK } \\
\text { signaling axis }\end{array}$ \\
\hline $\begin{array}{l}\text { Vallen et al. } \\
{[33]}\end{array}$ & 2014 & $\begin{array}{l}\text { To study the mechanistic role of CSE in providing adhesiveness to tumor cells } \\
\text { forming spheroids and cell migration }\end{array}$ & $\begin{array}{l}\text { Chondroitin sulfate } \mathrm{E} \\
\text { (CSE) rich motifs }\end{array}$ \\
\hline
\end{tabular}

\section{TABLE 4: Objectives and Potential Therapeutic Targets}

UPAR-FPR1: urokinase plasminogen activator receptor-formyl peptide receptor 1, AAM: alternatively activated macrophages, MCA: multicellular aggregates, TGF $\beta$ : transforming growth factor- $\beta$, HDAC4: histone deacetylase 4, MAPK7: mitogen-activated protein kinase 7, PAK2: p21 activated kinase 2, CSE: chondroitin sulfate $\mathrm{E}$

Combating the Chemotherapeutic Resistance

The amount of collagen in the tumor microenvironment regulates the response to chemotherapeutic drugs. Yeung et al. showed that cancer-associated fibroblasts (CAFs) secretes microfibril associated protein 5 (MFAP5), which causes increased expression of fibrosis-related genes thus, increasing the amount of collagen, which together with decreasing microvessel stability (more leakiness of vessels) leads to hindrance in the delivery of drugs [10]. Another study showed improved response to chemotherapy in patients who were given Losartan along with the standard therapy. Losartan decreases the number of fibroblasts, upregulates antifibrotic miRNA decreasing the ECM content (collagen type I levels), and thus reduce the solid stress, which improves drug delivery [6]. In another study, doxorubicin diffusion was impaired due to increased collagen accumulation in the tumor microenvironment due to decreased susceptibility to proteolytic enzymes caused by a serine protease inhibitor Maspin. Tumor growth was significantly inhibited when the anti-Maspin antibody was given along with doxorubicin compared to doxorubicin alone [35].

Resistance to cisplatin was found to be governed by a tumor suppressor microRNA. In 2017, Deng et al. showed decreased expression of miR-199a-3p led to enhanced Dicoidin domain receptor-1 (DDR1) expression, which was responsible for resistance to cisplatin [34]. Dexamethasone (DEX) enhances fibronectin (FN) expression and mucin 16, responsible for its pro adhesive, pro-survival effects and protects cancer cells from chemotherapeutic agents. Inhibition of fibronectin with FN-siRNA and mucin 16 with MUC-siRNA attenuated the effects [18]. Ovarian cancer cells up-regulate the expression of a Microtubuleassociated protein, which causes resistance to paclitaxel. Tau protein binds with microtubules and competes with paclitaxel for the binding site. Thus, enhanced Tau protein expression in ovarian cancer leads to resistance [11]. Table 5 below highlights the objectives and potential therapeutic targets of the included studies $[6,10,11,18,34,35]$. 


\section{Cureus}

\begin{tabular}{|c|c|c|c|}
\hline Authors & $\begin{array}{l}\text { Year of } \\
\text { publication }\end{array}$ & Purpose of the study & $\begin{array}{l}\text { Potential therapeutic } \\
\text { target }\end{array}$ \\
\hline $\begin{array}{l}\text { Yeung et } \\
\text { al. [10] }\end{array}$ & 2019 & $\begin{array}{l}\text { To elucidate the effect of MFAP5 blockade on tumor growth, fibrosis, blood } \\
\text { vessel stability, and chemotherapeutic response to drugs }\end{array}$ & MFAP5 \\
\hline $\begin{array}{l}\text { Zhao et } \\
\text { al. [6] }\end{array}$ & 2019 & $\begin{array}{l}\text { To study the role of losartan in improving the chemotherapeutic efficacy of } \\
\text { drugs and decreasing ascites }\end{array}$ & $\begin{array}{l}\text { Combining Losartan with } \\
\text { standard treatment }\end{array}$ \\
\hline $\begin{array}{l}\text { Deng et } \\
\text { al. [34] }\end{array}$ & 2017 & $\begin{array}{l}\text { To elucidate the role of microRNA miR-199a-3p/DDR1 pathway on tumor } \\
\text { migration, invasion, and drug resistance }\end{array}$ & DDR1 \\
\hline Yin et al. & 2016 & $\begin{array}{l}\text { To assess the effect of dexamethasone (a glucocorticoid) on tumor cell } \\
\text { adhesion, survival, and resistance to chemotherapy }\end{array}$ & $\begin{array}{l}\text { Fibronectin receptors, } \\
\text { MUC1 }\end{array}$ \\
\hline $\begin{array}{l}\text { Gurler et } \\
\text { al. [11] }\end{array}$ & 2015 & $\begin{array}{l}\text { To assess the response to paclitaxel in ovarian tumors with increased Tau } \\
\text { protein expression }\end{array}$ & $\begin{array}{l}\text { Inhibition of Tau protein } \\
\text { expression }\end{array}$ \\
\hline $\begin{array}{l}\text { Triulzi et } \\
\text { al. [35] }\end{array}$ & 2014 & To study the role of Maspin in chemotherapeutic response to doxorubicin & Maspin \\
\hline
\end{tabular}

\section{TABLE 5: Objectives and Potential Therapeutic Targets}

MFAP: microfibril associated protein, DDR1: discoidin domain receptor-1, MUC1: Mucin antigen 1

Strengths and Limitations

To the best of our knowledge, this is to date the only traditional review gathering all the information regarding molecular mechanisms underlying the ovarian cancer metastasis addressing the interaction between tumor cells, peritoneal mesothelial cells, and the extracellular matrix discovered in the last seven years published in the English language in PubMed. The details of how tumor cells spread are described in these studies; however, what happens to the tumor cell structure, any configurational change in the enzymes, receptors, and other signaling molecules involved is not explained. The structural component of metastasis can be a topic of research in the future. Tumor cell interaction with peritoneum is well described in this review, but how do tumor cells initially travel from ovary to peritoneum have not been detailed in the studies and can be researched upon. The studies included in this review are done on human tissue samples and cell lines. Animal models were also used. This warrants the need to corroborate the findings in randomized control trials.

\section{Conclusions}

The signaling molecules and pathways encountered in disseminating ovarian cancer and drug response lie in the peritoneum and extracellular matrix. Tumor cells detach from their primitive location on the ovaries and travel through the matrix to reach metastatic sites such as the peritoneum. They interact with peritoneal mesothelial cells and establish new sites for tumor growth and proliferation. Based on the reviewed articles, we found a substantial relationship between hypoxia, matrix remodeling enzymes, and disease progression. Several genes, their mRNAs, and subsequent proteins have been identified to alter patients' overall survival. There is a cascade of enzymes, receptors working in harmony to promote metastasis. The emerging chemotherapeutic resistance imposes great difficulties in treating patients, and targeting these molecular mechanisms has shown an improved response to the therapy. There is no good screening method available for early diagnosis before the patient develops metastasis. Studies focusing on finding a suitable marker for screening should be done. If studied in detail with more experimental studies and possibly targeted, the mechanisms highlighted in this review may enhance the quality of care and reduce the disease burden.

\section{Additional Information \\ Disclosures}

Conflicts of interest: In compliance with the ICMJE uniform disclosure form, all authors declare the following: Payment/services info: All authors have declared that no financial support was received from any organization for the submitted work. Financial relationships: All authors have declared that they have no financial relationships at present or within the previous three years with any organizations that might have an interest in the submitted work. Other relationships: All authors have declared that there are no other relationships or activities that could appear to have influenced the submitted work.

\section{References}


1. Torre LA, Trabert B, DeSantis CE, et al.: Ovarian cancer statistics, 2018. CA Cancer J Clin. 2018, 68:284-296. 10.3322/caac. 21456

2. Tan DS, Agarwal R, Kaye SB: Mechanisms of transcoelomic metastasis in ovarian cancer . Lancet Oncol. 2006, 7:925-934. 10.1016/S1470-2045(06)70939-1

3. Iwanicki MP, Davidowitz RA, Ng MR, et al.: Ovarian cancer spheroids use myosin-generated force to clear the mesothelium. Cancer Discov. 2011, 1:144-157. 10.1158/2159-8274.CD-11-0010

4. Natarajan S, Foreman KM, Soriano MI, et al.: Collagen remodeling in the hypoxic tumor-mesothelial niche promotes ovarian cancer metastasis. Cancer Res. 2019, 79:2271-2284. 10.1158/0008-5472.CAN-18-2616

5. Zhang H, Yang Q, Lian X, Jiang P, Cui J: Hypoxia-inducible factor-1 $\alpha$ (HIF- $1 \alpha$ ) promotes hypoxia-induced invasion and metastasis in ovarian cancer by targeting matrix metallopeptidase 13 (MMP13). Med Sci Monit. 2019, 25:7202-7208. 10.12659/MSM.916886

6. Zhao Y, Cao J, Melamed A, et al.: Losartan treatment enhances chemotherapy efficacy and reduces ascites in ovarian cancer models by normalizing the tumor stroma. Proc Natl Acad Sci U S A. 2019, 116:2210-2219. 10.1073/pnas.1818357116

7. Fogg KC, Olson WR, Miller JN, et al.: Alternatively activated macrophage-derived secretome stimulates ovarian cancer spheroid spreading through a JAK2/STAT3 pathway. Cancer Lett. 2019, 458:92-101. 10.1016/j.canlet.2019.05.029

8. Dai J, Wang T, Wang W, Zhang S, Liao Y, Chen J: Role of MAPK7 in cell proliferation and metastasis in ovarian cancer. Int J Clin Exp Pathol. 2015, 8:10444-10451.

9. Samardzija C, Luwor RB, Quinn MA, Kannourakis G, Findlay JK, Ahmed N: Coalition of Oct4A and $\beta 1$ integrins in facilitating metastasis in ovarian cancer. BMC Cancer. 2016, 16:432. 10.1186/s12885-016-2458-Z

10. Yeung TL, Leung CS, Yip KP, et al.: Anticancer immunotherapy by MFAP5 blockade inhibits fibrosis and enhances chemosensitivity in ovarian and pancreatic cancer. Clin Cancer Res. 2019, 25:6417-6428. 10.1158/1078-0432.CCR-19-0187

11. Gurler H, Yu Y, Choi J, Kajdacsy-Balla AA, Barbolina MV: Three-dimensional collagen type I matrix upregulates nuclear isoforms of the microtubule-associated protein tau implicated in resistance to paclitaxel therapy in ovarian carcinoma. Int J Mol Sci. 2015, 16:3419-3433. 10.3390/ijms16023419

12. Guo B, Yan H, Li L, Yin K, Ji F, Zhang S: Collagen triple helix repeat containing 1 (CTHRC1) activates integrin $\beta 3$ /FAK signaling and promotes metastasis in ovarian cancer. J Ovarian Res. 2017, 10:69. 10.1186/s13048-017-0358-8

13. Grither WR, Divine LM, Meller EH, et al.: TWIST1 induces expression of discoidin domain receptor 2 to promote ovarian cancer metastasis. Oncogene. 2018, 37:1714-1729. 10.1038/s41388-017-0043-9

14. Minopoli M, Botti G, Gigantino V, et al.: Targeting the Formyl Peptide Receptor type 1 to prevent the adhesion of ovarian cancer cells onto mesothelium and subsequent invasion. J Exp Clin Cancer Res. 2019, 38:459. 10.1186/s13046-019-1465-8

15. Cheon DJ, Tong Y, Sim MS, et al.: A collagen-remodeling gene signature regulated by TGF- $\beta$ signaling is associated with metastasis and poor survival in serous ovarian cancer. Clin Cancer Res. 2014, 20:711-723. 10.1158/1078-0432.CCR-13-1256

16. Bruney L, Liu Y, Grisoli A, Ravosa MJ, Stack MS: Integrin-linked kinase activity modulates the prometastatic behavior of ovarian cancer cells. Oncotarget. 2016, 7:21968-21981. 10.18632/oncotarget.7880

17. Shen YF, Wei AM, Kou Q, Zhu QY, Zhang L: Histone deacetylase 4 increases progressive epithelial ovarian cancer cells via repression of p21 on fibrillar collagen matrices. Oncol Rep. 2016, 35:948-954. 10.3892/or.2015.4423

18. Yin L, Fang F, Song X, et al.: The pro-adhesive and pro-survival effects of glucocorticoid in human ovarian cancer cells. J Mol Endocrinol. 2016, 57:61-72. 10.1530/JME-15-0142

19. Sun L, Lin P, Qin Z, Liu Y, Deng LL, Lu C: Hypoxia promotes HO-8910PM ovarian cancer cell invasion via Snail-mediated MT1-MMP upregulation. Exp Biol Med (Maywood). 2015, 240:1434-1445. $10.1177 / 1535370215570205$

20. Bruney L, Conley KC, Moss NM, Liu Y, Stack MS: Membrane-type I matrix metalloproteinase-dependent ectodomain shedding of mucin16/ CA-125 on ovarian cancer cells modulates adhesion and invasion of peritoneal mesothelium. Biol Chem. 2014, 395:1221-1231. 10.1515/hsz-2014-0155

21. Liu J, Liu Q, Wang Y, Liu M, Qi Y, Gao J, Lin B: Co-expression of Lewis y antigen and CD147 in epithelial ovarian cancer is correlated with malignant progression and poor prognosis. Int J Mol Med. 2019, 43:16871698. 10.3892/ijmm.2019.4103

22. Klymenko Y, Kim O, Loughran E, Yang J, Lombard R, Alber M, Stack MS: Cadherin composition and multicellular aggregate invasion in organotypic models of epithelial ovarian cancer intraperitoneal metastasis. Oncogene. 2017, 36:5840-5851. 10.1038/onc.2017.171

23. Li Y, Zhou J, Wang J, Chen X, Zhu Y, Chen Y: Mir-30b-3p affects the migration and invasion function of ovarian cancer cells by targeting the CTHRC1 gene. Biol Res. 2020, 53:10. 10.1186/s40659-020-00277-4

24. Wahab NA, Othman Z, Nasri NWM, et al.: Inhibition of miR-141 and miR-200a increase DLC-1 and ZEB2 expression, enhance migration and invasion in metastatic serous ovarian cancer. Int J Environ Res Public Health. 2020, 17:2766. 10.3390/ijerph17082766

25. Chan CK, Pan Y, Nyberg K, et al.: Tumour-suppressor microRNAs regulate ovarian cancer cell physical properties and invasive behaviour. Open Biol. 2016, 6:160275. 10.1098/rsob.160275

26. Ye J, Chen W, Wu ZY, et al.: Up-regulated CTHRC1 promotes human epithelial ovarian cancer invasion through activating EGFR signaling. Oncol Rep. 2016, 36:3588-3596. 10.3892/or.2016.5198

27. Price JC, Azizi E, Naiche LA, et al.: Notch3 signaling promotes tumor cell adhesion and progression in a murine epithelial ovarian cancer model. PLoS One. 2020, 15:0233962. 10.1371/journal.pone.0233962

28. Flate E, Stalvey JR: Motility of select ovarian cancer cell lines: effect of extracellular matrix proteins and the involvement of PAK2. Int J Oncol. 2014, 45:1401-1411. 10.3892/ijo.2014.2553

29. Klymenko Y, Wates RB, Weiss-Bilka H, et al.: Modeling the effect of ascites-induced compression on ovarian cancer multicellular aggregates. Dis Model Mech. 2018, 11:034199. 10.1242/dmm.034199

30. Klymenko Y, Johnson J, Bos B, Lombard R, Campbell L, Loughran E, Stack MS: Heterogeneous cadherin expression and multicellular aggregate dynamics in ovarian cancer dissemination. Neoplasia. 2017, 19:549- 


\section{Cureus}

563. 10.1016/i.neo.2017.04.002

31. Choi PW, Yang J, Ng SK, et al.: Loss of E-cadherin disrupts ovarian epithelial inclusion cyst formation and collective cell movement in ovarian cancer cells. Oncotarget. 2016, 7:4110-4121. 10.18632/oncotarget.6588

32. Pettee KM, Dvorak KM, Nestor-Kalinoski AL, Eisenmann KM: An mDia2/ROCK signaling axis regulates invasive egress from epithelial ovarian cancer spheroids. PLoS One. 2014, 9:90371.

10.1371/journal.pone.0090371

33. Vallen MJ, Schmidt S, Oosterhof A, Bulten J, Massuger LF, van Kuppevelt TH: Primary ovarian carcinomas and abdominal metastasis contain 4,6-disulfated chondroitin sulfate-rich regions, which provide adhesive properties to tumor cells. PLoS One. 2014, 9:111806. 10.1371/journal.pone.0111806

34. Deng Y, Zhao F, Hui L, et al.: Suppressing miR-199a-3p by promoter methylation contributes to tumor aggressiveness and cisplatin resistance of ovarian cancer through promoting DDR1 expression. J Ovarian Res. 2017, 10:50. 10.1186/s13048-017-0333-4

35. Triulzi T, Ratti M, Tortoreto M, et al.: Maspin influences response to doxorubicin by changing the tumor microenvironment organization. Int J Cancer. 2014, 134:2789-2797. 10.1002/ijc.28608 